\title{
Knowledge pattern assessment of potential safety threats of compact fluorescent lamps in Kuwait
}

\author{
Abdullah Alsanad* iD \\ Department of Environment Technology Management (ETM), College of Life Sciences, Kuwait \\ University, Kuwait \\ Azel Almutairi \\ Department of Environment Technology Management (ETM), College of Life Sciences, Kuwait \\ University, Kuwait

\section{Heba Alhelailah} \\ Department of Environment Technology Management (ETM), College of Life Sciences, Kuwait \\ University, Kuwait \\ *Corresponding author. Email: abdullah.alsanad@ku.edu.kw
}

\section{How to Cite}

Alsanad, A. et al. (2021). Knowledge pattern assessment of potential safety threats of compact fluorescent lamps in Kuwait. Journal of Applied and Natural Science, 13(4), 1256 - 1264. https://doi.org/10.31018/jans.v13i4.3007

\begin{abstract}
Globally, compact fluorescent lamps (CFLs) are increasing consistently, and Kuwait is not an exception. However, these lamps contain mercury, which is highly injurious to human health and the environment. This study assessed Kuwaiti respondents' awareness using a large-scale national survey conducted on a random sample of 6210 individuals (response rate $84.3 \%$ ). The questionnaire was comprised of four sections and utilized skip logic branching. The modes were paper-based, face-to-face interviews, and electronic structured questionnaires. Data were also analyzed through the Pearson chisquare test to know the significant differences in lamp type preferences and the reasons for the preferences. Almost half of the participants $(51.4 \%)$ knew the difference between incandescent and fluorescent lamps. Only $11.1 \%$ were using incandescent lamps solely in their houses. The remaining $88.9 \%$ used fluorescent lamps $(38.4 \%)$ or both types $(50.5 \%)$. The results showed that $48.3 \%$ think fluorescent lamps save energy, whereas $81.3 \%$ of people were unaware of their mercury content. The knowledge patterns towards breakage showed that respondents who chose the proper response were $31.9 \%$ for evacuation, $14.6 \%$ for aeration, and $7.3 \%$ for turning off the AC. The awareness of populations to take appropriate actions towards proper disposal was very poor in case of fluorescent lamp accidental breakage or when it completes its life cycle because most of them did not know about the proper evacuation, aeration, and cleanup measures. These findings are beneficial for the government and policymakers to take essential steps to create relevant awareness channels among the country's communities for safety from expected health hazards.
\end{abstract}

Keywords: Compact fluorescent lamp, Energy saving, Kuwait, Mercury, Ultraviolet

\section{INTRODUCTION}

Compared to incandescent light bulbs, compact fluorescent light bulbs are more energy-efficient and last longer. Fluorescent lamps were discovered in 1925 (Khan and Abas, 2011, Pode, 2020). There are different sizes and shapes for compact fluorescent lamps (CFLs), and their compactness comes from a folded-tube technology. Compact fluorescent light bulbs can produce a similar colour to incandescent lamps due to the premium colour phosphors (Brautigan, 1997, Gaffur et al., 2021). The luminous power of a $23 \mathrm{~W}$ compact fluorescent light bulb is comparable to a $100 \mathrm{~W}$ incandescent bulb. The input power to a white light conversion of CFLs is from 6.6 to $8.8 \%$, whereas it is only $2.6 \%$ in an incan- descent lightbulb. Over its estimated $6000-15,000 \mathrm{~h}$ lifespan, compact fluorescent lights save 30 dollars over traditional bulbs due to lasting up to 10 times more prolonged and consuming up to 5 times less power (Ngoffe, 2019, Khan and Abas, 2011). The efficiency of CFLs decreases with extreme temperatures because the optimal operating temperature is $20^{\circ} \mathrm{C}$. Hence, CFLs are not suitable for microwaves and refrigerators (Khan and Abas, 2011). Increased greenhouse gas emissions in the atmosphere contribute to the enhanced greenhouse effect (Hansen et al., 1981), which is directly related to energy consumption. The higher the consumption of energy, the higher the concentration of greenhouse gases. This has led many communities to energy-saving appliances, such as compact fluo- 
rescent lamps (CFLs) and light-emitting diode (LED) lamps. Unlike the United States and European countries, which rely partially on alternative sources for power, almost all of the electricity generated in Kuwait is produced by burning fossil fuels, primarily oil and natural gas (Ansari and Holtz, 2020, USEIA, 2016). It was recently reported that in 2015 , the $\mathrm{CO}_{2}$ emissions from the Kuwaiti-based fossil fuel power plants were an estimated 34 million tons, which might double in less than ten years (Abotalib et al., 2021).

The long lifespan of compact fluorescent lamps (Brautigan, 1997) and their energy-saving properties make them very economical compared to traditional incandescent lamps. The problem with CFLs is that they contain trace amounts of mercury (Dunmire et al., 2003). Exposure to high mercury levels can adversely affect the digestive, nervous, renal, and ocular systems, as well as the overall development of organs (ATSDR, 2011). A typical CFL bulb is coated with phosphor and contains argon and mercury vapours. When electricity passes between the fixed electrodes, the contained gases get excited and release an ultraviolet (UV) light; this invisible light excites the phosphor coating making the light visible at the color we see. Studies have shown that the metal content of CFLs is higher than that of incandescent light bulbs. Compared to incandescent bulbs, compact fluorescent lamps contain more antimony, copper, iron, lead, mercury, yttrium, and zinc. CFLs work bypassing AC between the fixed electrodes, which excites the mercury atoms and make them release invisible ultraviolet light (UV), which becomes visible light once it comes in contact with the inside fluorescent coating (phosphor) of the glass tube (Lim et al., 2013). Spent fluorescent lamps contain between 0.7 and 115 mg of mercury per lamp (Jang et al., 2005). The compact fluorescent lamps category averages 3 to $5 \mathrm{mg}$ of mercury per lamp (Johnson et al., 2008). Usually, the higher the wattage, the higher the amount of mercury in CFLs. To limit the amount of mercury, the National Electrical Manufacturers Association (NEMA) requires manufacturers to use a maximum of $5 \mathrm{mg} \mathrm{Hg}$ for $25 \mathrm{~W}$ CFLs or smaller wattage and $6 \mathrm{mg} \mathrm{Hg}$ for higher wattage CFLs. Since manufacturers are producing lower mercury versions, the actual mercury content in compact fluorescent is approximately 3 to $4 \mathrm{mg} / \mathrm{lamp}$. This amount of mercury is minimal compared to oral thermometers, which may contain up to 1 gram or 200 times the amount of mercury found in CFLs (NEMA, 2018). This is of more concern when additional sources of mercury are taken daily, for example, by consuming certain types of seafood, vegetables, and fruits. Over the CFLs lifespan, the contained mercury gets absorbed by the glass tubes and electrodes. If this continues and the mercury is depleted, the light colour changes to dark pink. According to CFL manufacturers, there is $0.012 \mathrm{mg} \mathrm{Hg}$ loss per kilowatt-hour (Khan and Abas,
2011).

Kuwait has one of the highest kilowatt per capita rates globally and ranked fourth with $15,591 \mathrm{kWh} /$ capita (OECD/IEA, 2014). This high electric power consumption can be attributed to Kuwaiti citizens' high standard of living and the climate of Kuwait. The summer temperature in Kuwait can reach $54^{\circ} \mathrm{C}$ (SKDGCA, 2017), which increases the need for air conditioning systems and the associated electrical load. The objective of this study is to assess CFLs' knowledge patterns in society. Knowledge assessment involved the difference between compact fluorescent lamps and the traditional incandescent lamps, the presence of mercury in compact fluorescent lamps, mercury impacts on human health and the environment, handling and cleaning procedure in case of the breakage of CFLs, and lastly, the fate of the spent compact fluorescent lamps. The awareness assessment was conducted by employing questionnaires served to the participants from all of Kuwait's governorates.

\section{MATERIALS AND METHODS}

\section{Study area and respondents}

A large-scale national survey was conducted on a random sample of the Kuwaiti population to have a holistic perspective of respondents' awareness levels. The survey was distributed to 6210 individuals. The number of people who completed the questionnaire was 5237, a completion rate of 84.3 percent. Participants belonged to various groups of age, gender, education, and nationality (expatriates). The respondents represented all the six governorates of Kuwait: Asima, Hawalli, Farwaniya, Mubarak Alkabeer, Ahmadi, and Jahra.

\section{Questionnaire design}

The questionnaire comprised 19 questions divided into four major sections (Fig.1- population demographics (1), the types of lamps used in the local market (2), the respondents' preferences, how people deal with breakage or disposal (3), and mercury knowledge and risk factors (4). The skip logic branching technique was utilized through multiple survey parts to improve the questionnaire outcomes (SurveyMonkey Inc., 2020). Skip logic customizes the path respondents take while answering the survey; in other words, future questions are shown based on current answers. It was used, for example, to exclude those who do not know the difference between incandescent light bulbs and CFLs from answering the question about the presence of mercury in CFLs. Skip logic branching also tends to filter out irrelevant data and make the survey shorter, increasing the chances of completion. It should be noted that most of the questions were derived from the literature examining mercury fate and transport (Murphy et al., 2018, SurveyMonkey Inc., 2020). 


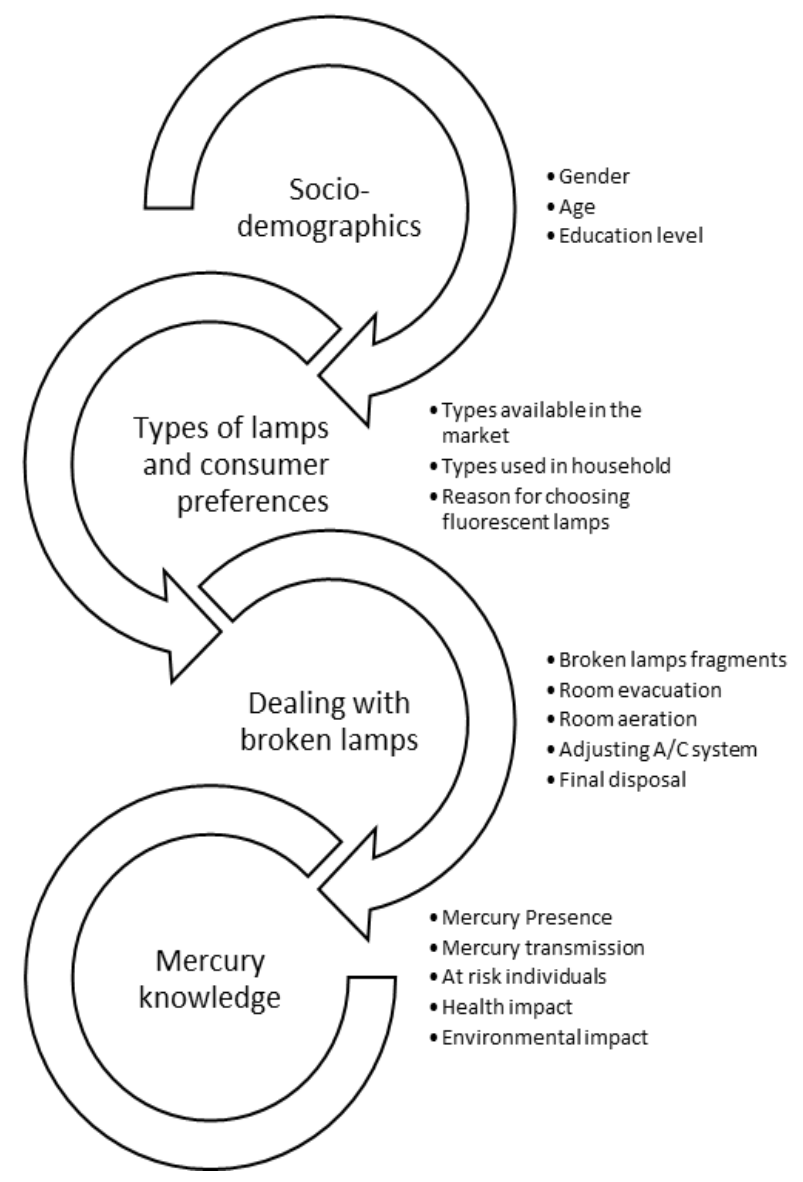

Fig. 1. Survey Structure of the population of Kuwait

\section{Data collection and analysis}

The methods used to collect the data were paperbased questionnaires, face-to-face interviews, and electronic structured questionnaires. The face-to-face survey mode was mainly aimed at the elderly and those who have a reading disadvantage. A total number of 38 collectors helped in gathering the questionnaires. After the data collection process, IBM's Statistical Package for the Social Sciences (SPSS) software (IBM, 2019) was used for data analysis.

\section{RESULTS AND DISCUSSION}

\section{Socio-demographics and respondents' characteristics} The replies to the socio-demographic questions (Table 1) showed that 1177 males with a percentage of $22.5 \%$, had completed the survey. The number of females was 4060 , forming $77.5 \%$ of the sample. The age structure revealed that most respondents $(69.1 \%)$ were of college and early career (18-39 years old). The education level of the respondents is relatively high because $17.1 \%$ have a college diploma, $59 \%$ of them hold a bachelor's degree, and $7 \%$ hold a graduate degree. Thus, respondents with higher education comprised $83 \%$ of the overall study sample. The spatial distribution of the survey respondents indicated that most of them reside $(24.4 \%)$ in the Asima governorate, followed by Hawalli $(22.3 \%)$. Both governorates comprise almost half of the respondents $(46.7 \%)$, and the rest belong to the other four governorates.

\section{Types of lamps and consumers' preferences}

The second set of questions focused on the types of lamps people used in their houses and why they used them instead of other lamps. The first question in this set asked if they knew the types of lamps available in the market; if their answer was no, they were provided with an image showing the different types of lamps. This ensures the accuracy of the rest of the survey questions, which focus primarily on fluorescent lamps. Once informed, the respondents were asked about the types of lamps used in their houses. The survey results showed that fluorescent lamps are hugely popular among the Kuwaiti population, as $50.5 \%$ use both types of lamps, while $38.4 \%$ use fluorescent lamps exclusively. The incandescent lamp participants were only $11.1 \%$, significantly lesser $(P<0.001$, Table 2$)$. Whether the participants knew about the types of lamps available in the market or not, the tendency to use incandescent lamps remains significantly low $(P<0.001$, Post hoc test).

Respondents preferred using fluorescent lamps either due to the relatively long lifespan (58.5\%), or energysaving properties $(48.3 \%)$, market availability $(14.8 \%)$, and cost $(9.8 \%)$. This question was a multiple answer question where overlapping preferences are allowed (Table 3). As shown in Fig. 2, the study sample preferred fluorescent lamps primarily for their long lifespan and energy-saving properties. The figure also shows that despite the popularity of fluorescent, relatively low cost and market availability are not the driving factors for usage.

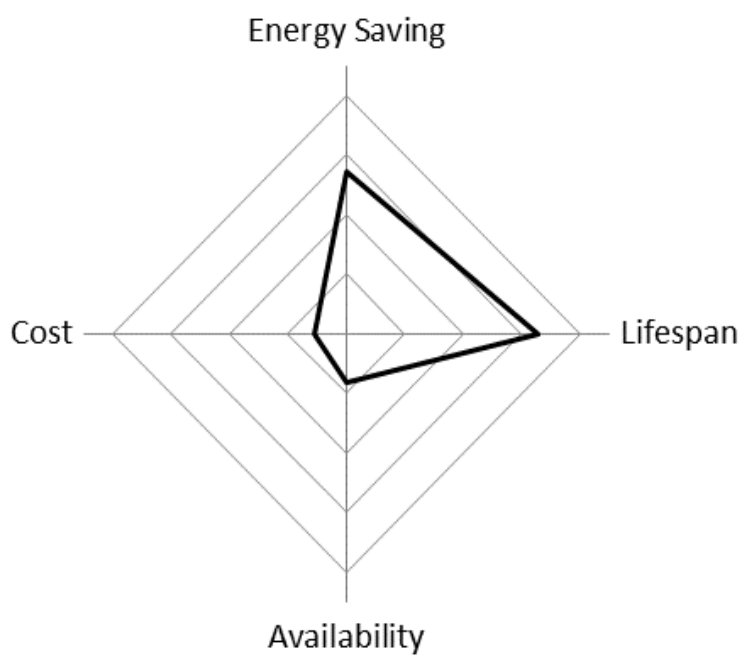

Fig. 2. Factors affecting the respondents' preferences towards fluorescent lamps 
Table 1. Frequency distribution $(n)$ of demographics and other characteristics of the respondents' (\% in parenthesis) of Kuwait

\begin{tabular}{|c|c|c|c|c|c|c|c|}
\hline Respondents & Total & Asima & Hawalli & Farwaniya & $\begin{array}{l}\text { Mubarak } \\
\text { Alkabeer }\end{array}$ & Ahmadi & Jahra \\
\hline Total & 5237 & $1278(24.4)$ & $1170(22.3)$ & $704(13.4)$ & $775(14.8)$ & $769(14.7)$ & $541(10.3)$ \\
\hline \multicolumn{8}{|c|}{ Gender } \\
\hline Male & $\begin{array}{l}1177 \\
(22.5)\end{array}$ & $297(5.7)$ & $288(5.5)$ & $157(3.0)$ & $169(3.2)$ & $152(2.9)$ & $114(2.2)$ \\
\hline Female & $\begin{array}{l}4060 \\
(77.5) \\
\end{array}$ & $981(18.7)$ & $882(16.8)$ & $547(10.4)$ & $606(11.6)$ & $617(11.8)$ & $427(8.2)$ \\
\hline \multicolumn{8}{|c|}{ Age Structure } \\
\hline$<17$ & $281(5.4)$ & $77(1.5)$ & $52(1.0)$ & $42(0.8)$ & $30(0.6)$ & $43(0.8)$ & $37(0.7)$ \\
\hline $18-22$ & $\begin{array}{l}1394 \\
(26.6)\end{array}$ & $311(5.9)$ & $249(4.8)$ & 186 (3.6) & $207(4.0)$ & $235(4.5)$ & 206 (3.9) \\
\hline $23-29$ & $\begin{array}{l}1040 \\
(19.9)\end{array}$ & $244(4.7)$ & $175(3.3)$ & $150(2.9)$ & $206(3.9)$ & $161(3.1)$ & $104(2.0)$ \\
\hline $30-39$ & $\begin{array}{l}1078 \\
(20.6)\end{array}$ & $237(4.5)$ & $282(5.4)$ & $146(2.8)$ & $143(2.7)$ & $157(3.0)$ & $113(2.2)$ \\
\hline $40-49$ & $871(16.6)$ & $217(4.1)$ & $264(5.0)$ & $116(2.2)$ & $83(1.6)$ & $119(2.3)$ & $72(1.4)$ \\
\hline $50-59$ & $501(9.6)$ & $167(3.2)$ & $124(2.4)$ & $60(1.1)$ & $96(1.8)$ & $49(0.9)$ & $5(0.1)$ \\
\hline$>60$ & $72(1.4)$ & $25(0.5)$ & $24(0.5)$ & $4(0.1)$ & $10(0.2)$ & $5(0.1)$ & $4(0.1)$ \\
\hline \multicolumn{8}{|c|}{ Education level } \\
\hline $\begin{array}{l}\text { Below } \\
\text { secondary school }\end{array}$ & $222(4.2)$ & $52(1.0)$ & $32(0.6)$ & $31(0.6)$ & $39(0.7)$ & $35(0.7)$ & $33(0.6)$ \\
\hline $\begin{array}{l}\text { Secondary } \\
\text { school }\end{array}$ & $664(12.7)$ & $136(2.6)$ & $122(2.3)$ & $92(1.8)$ & $97(1.9)$ & $119(2.3)$ & $98(1.9)$ \\
\hline $\begin{array}{l}\text { College } \\
\text { diploma }\end{array}$ & $896(17.1)$ & $188(3.6)$ & $213(4.1)$ & $123(2.3)$ & $155(3.0)$ & $147(2.8)$ & $70(1.3)$ \\
\hline $\begin{array}{l}\text { Bachelor's } \\
\text { degree }\end{array}$ & $\begin{array}{l}3088 \\
(59.0)\end{array}$ & $802(15.3)$ & $690(13.2)$ & $412(7.9)$ & $437(8.3)$ & $429(8.2)$ & $318(6.1)$ \\
\hline $\begin{array}{l}\text { Graduate } \\
\text { degree }\end{array}$ & $367(7.0)$ & $100(1.9)$ & $113(2.2)$ & $46(0.9)$ & $47(0.9)$ & $39(0.7)$ & $22(0.4)$ \\
\hline
\end{tabular}

Table 2. Use of different types of lamps in houses of Kuwait

\begin{tabular}{lllll}
\hline $\begin{array}{l}\text { Options to be } \\
\text { selected by the } \\
\text { participants }\end{array}$ & Frequency & Percentage (\%) & $\begin{array}{l}\text { Pearson } \\
\text { Chi-Square }\end{array}$ & P \\
\hline Incandescent lamps & 580 & 11.1 & \\
Fluorescent lamps & 2012 & 38.4 & 49.7 & $<0.001^{\text {a }}$ \\
Both types of lamps & 2645 & 50.5 & \\
Total & 5237 & 100.0 &
\end{tabular}

${ }^{a}$ Appendix 2.1a; ${ }^{b}$ Significant differences among the categories (Post hoc test with Bonferroni adjustment, Appendix 2.1b)

Knowledge patterns towards mercury presence and transport

The core question in the questionnaire was whether the respondents knew that fluorescent lamps contained mercury or not. Surprisingly, most respondents (81.6\%) were unaware that mercury was present in fluorescent lamps (Table 4). One would assume that higher levels of education ( $83 \%$ of the study sample) would indicate better knowledge towards mercury presence. However, this did not prove to be the case because certain types of information might require special awareness. Dun- mire et al. (2003) and Jang, Hong, and Park (2005) indicated that fluorescent lamps contain mercury, which could injure human health if necessary care is not observed.

The survey participants were asked two questions regarding mercury's impact on human health and the environment. For both questions, the number of people who were not aware of the impacts of mercury was higher (Table 4). For the question, "Do you have any idea about the mercury impact on human health" 2355 respondents (45\%) answered yes, and 2882 respond- 


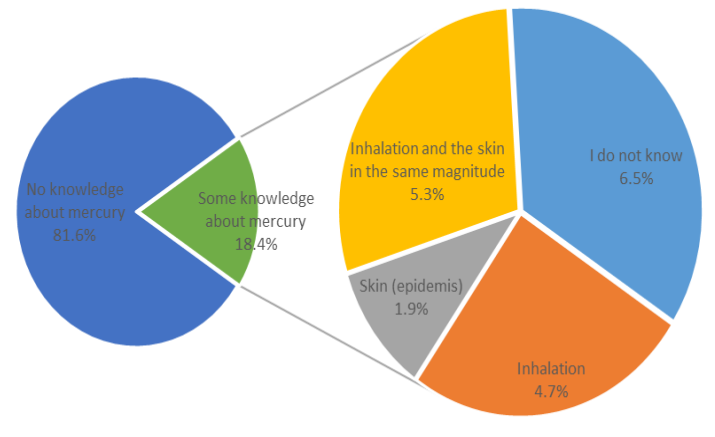

Fig. 3. Participants' view about the transmittance of mercury to humans after the breakage of a fluorescent lamp

ents (55\%) answered no. Regarding the second question, "Do you have any idea about the mercury impact on the environment" 1919 participants (36.6\%) answered yes, while the vast majority, numbering 3318 $(63.4 \%)$, answered no. Thus, the majority of the communities may be affected unknowingly because, after exposure, mercury can move and accumulate to various body tissues like the kidneys and can even cross the blood-brain barrier, resulting in neurotoxicity (IARC, 2018, Li et al., 2021).

The survey respondents also answered two questions, one about the routes of human exposure to mercury in case of lamp's breakage and the other about the indi-

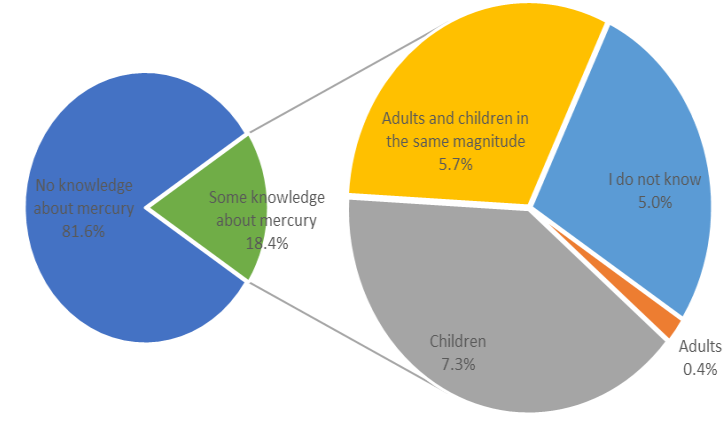

Fig. 4. Opinion of participants regarding the susceptibility of mercury to various groups of the population

viduals at-risk. The responses of participants were through inhalation (25.6\%), through the epidermis $(10.3 \%)$, through both; inhalation and epidermis $(28.29 \%)$, whereas the rest $(35.81 \%)$ had no idea regarding the transmission of mercury to humans (Fig. 3). According to literature, the primary route of mercury exposure in humans is through the ingestion of mercury, for example consuming contaminated fish (methyl mercury). Humans may be exposed to mercury vapor and compounds through inhalation and skin contact (Yang and Massey, 2019, Aucott et al., 2003). As for the at-risk individuals, $39.8 \%$ of the respondents chose children, $2.0 \%$ chose adults, $28.9 \%$ chose both children

Table 3. Reasons for using fluorescent lamps in houses of Kuwait

\begin{tabular}{lllll}
\hline $\begin{array}{l}\text { Options to be selected by the } \\
\text { participants }\end{array}$ & Frequency & Percentage (\%) & Pearson Chi-Square & P \\
\hline Fluorescent lamps are not used & 580 & 11.1 & \\
Fluorescent lamps save energy & 2529 & 48.3 & \\
Fluorescent lamps have a long life & 3066 & 58.5 & 7490.2 & $<0.001^{\mathrm{a}}$ \\
$\begin{array}{l}\text { Fluorescent lamps are readily } \\
\text { available in the market }\end{array}$ & 776 & 14.8 & \\
Fluorescent lamps are well priced & 511 & 9.6 & \\
\hline
\end{tabular}

Participants could select multiple answers. ${ }^{a}$ Appendix 2.2a); ${ }^{b}$ Post hoc test with Bonferroni adjustment (Appendix 2.2b)

Table 4. Awareness about the presence of mercury in fluorescent lamps and its impact on human health and the environment

\begin{tabular}{|c|c|c|c|c|c|c|c|c|}
\hline \multirow{2}{*}{$\begin{array}{l}\text { Options to be selected by the } \\
\text { participants }\end{array}$} & \multicolumn{3}{|c|}{ Frequency (Numbers n) } & \multicolumn{3}{|c|}{ Percentage (\%) } & \multirow[t]{2}{*}{$\begin{array}{l}\text { Pearson } \\
\text { Chi-Square }\end{array}$} & \multirow[t]{2}{*}{$\mathbf{P}$} \\
\hline & Yes & No & Total & Yes & No & Total & & \\
\hline $\begin{array}{l}\text { Awareness that Florescent } \\
\text { lamps contain mercury }\end{array}$ & 961 & 4276 & 5237 & 18.4 & 81.6 & 100.0 & \multirow{4}{*}{874.1} & \multirow{4}{*}{$<0.001^{\mathrm{a}}$} \\
\hline $\begin{array}{l}\text { Knowledge of mercury risk on } \\
\text { human health }\end{array}$ & 2355 & 2882 & 5237 & 45.0 & 55.0 & 100.0 & & \\
\hline $\begin{array}{l}\text { Knowledge of mercury risk on } \\
\text { the environment } \\
\text { Means of frequencies for the }\end{array}$ & 1919 & 3318 & 5237 & 36.6 & 63.4 & 100.0 & & \\
\hline above three options & 1745 & 3492 & 5237 & 17.9 & 82.1 & 100.0 & & \\
\hline
\end{tabular}

${ }^{a}$ Appendix 2.3 
Table 5. Awareness of participants regarding immediate actions required after a fluorescent lamp is broken

\begin{tabular}{|c|c|c|c|c|c|c|c|c|}
\hline \multirow{2}{*}{$\begin{array}{l}\text { Options to be } \\
\text { selected by the } \\
\text { participants }\end{array}$} & \multicolumn{3}{|c|}{ Frequency (Numbers n) } & \multicolumn{3}{|c|}{ Percentage (\%) } & \multirow{2}{*}{$\begin{array}{l}\text { Pearson } \\
\text { Chi-Square }\end{array}$} & \multirow[t]{2}{*}{$\mathbf{P}$} \\
\hline & Yes & No & Total & Yes & No & Total & & \\
\hline $\begin{array}{l}\text { Evacuation of the room } \\
\text { from all people }\end{array}$ & 1668 & 3569 & 5237 & 31.9 & 68.1 & 100.0 & \multirow{4}{*}{1132.1} & \multirow{4}{*}{$<0.001^{\circ}$} \\
\hline $\begin{array}{l}\text { Aeration of the room by } \\
\text { opening the }\end{array}$ & 765 & 4472 & 5237 & 14.6 & 85.4 & 100.0 & & \\
\hline $\begin{array}{l}\text { windows and doors } \\
\text { Turn off the air condi- } \\
\text { tioning system }\end{array}$ & 382 & 4855 & 5237 & 7.3 & 92.7 & 100.0 & & \\
\hline $\begin{array}{l}\text { Means of frequencies } \\
\text { for the above three } \\
\text { options }\end{array}$ & 938.33 & 4298.67 & 5237 & 17.9 & 82.1 & 100.0 & & \\
\hline
\end{tabular}

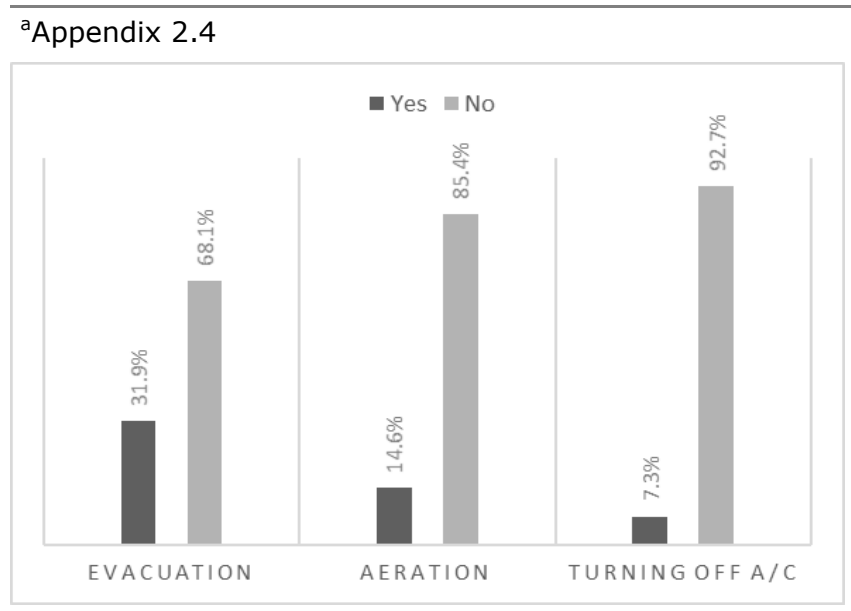

Fig. 5. Fluorescent lamps breakage response scenarios

and adults equally, while the rest had no idea and children are at a higher risk of mercury as exposure may impair the developing nervous system (Nance et al., 2011, Counter and Buchman, 2004).

\section{Knowledge patterns towards breakage, cleanup, and disposal of CFLs}

Most of the literature on fluorescent lamps focused on their components, composition, environmental impact, and disposal (Jang et al., 2005, ATSDR, 2011, Nance et al., 2011). Very few studies focused on the human response towards its breakage and cleaned up. This survey addressed these topics in a series of "if-then" questions (Fig. 4). Respondents who answered yes to these questions chose the proper response scenario since most of the mercury released after breakage is in the form of elemental vapor. Much of this release is during the first 8 hours (Nance et al., 2011). Under normal usage, fluorescent lamps remain intact. However, accidents happen, and sometimes they bust for no apparent reason. Almost $31.9 \%$ of participants indicated that they would evacuate the room versus $68.1 \%$ who do not act upon this practice after the breakage of fluorescent lamps (Table 5, Fig. 5). As for aerating the rooms by opening the doors and windows, 14.6 per- cent indicated they would aerate the affected room, while $85.4 \%$ of them will not do that, which might be due to the lack of awareness. Only $7.3 \%$ would turn off the air conditioning system, whereas $92.7 \%$ are of the view of keeping it running. The participants selecting the negative answer may not be well-versed in the urgency and benefits of turning the AC system off. There is a real need to educate them that mercury particles may be recycled in the room if the air conditioning system is running, and these particles could be dangerous for the room's inhabitants (Hill, 2020).

The respondents were then asked how they would collect the broken pieces, and their responses were; by a broom or bare hands $(44.5 \%)$, a vacuum cleaner $(35.6 \%)$, damp cloth $(8.3 \%)$, whereas the rest did not know how to do it (Fig. 6). These answers represent the lack of knowledge in dealing with lamp breakage as neither a broom nor a vacuum cleaner is recommended in cleaning the broken lamp fragments. Instead, the Health Protection Agency (2009) suggests refraining from using vacuum cleaners and household cleaning

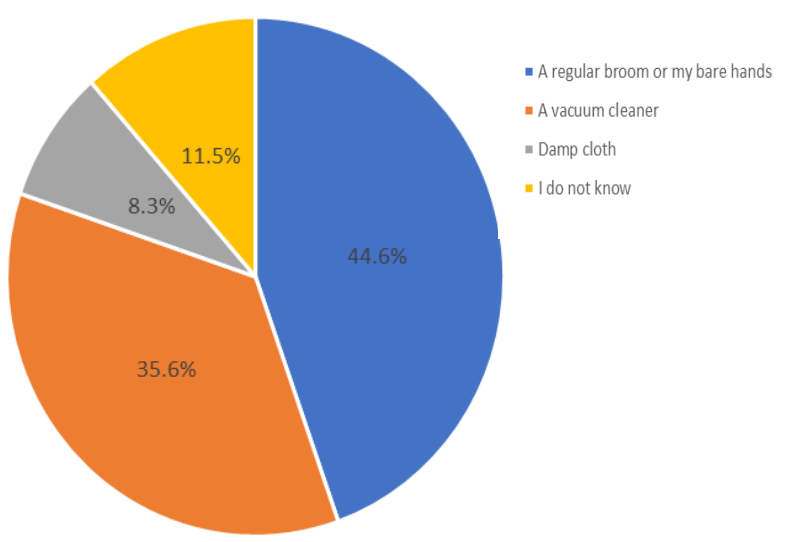

Fig. 6. Opinion of the participants of the survey regarding the cleanup method of the broken pieces of the fluorescent lamps 


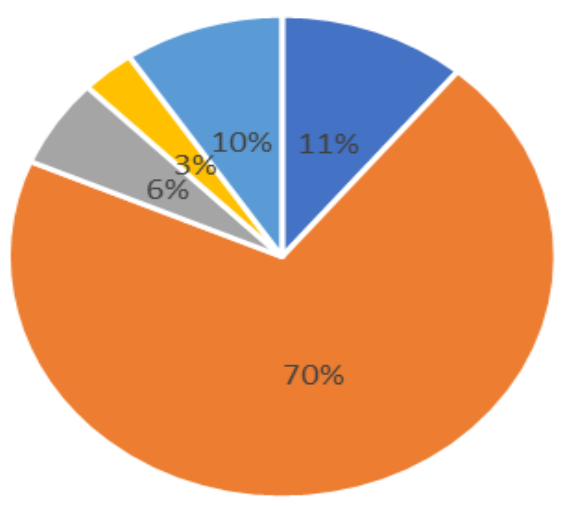

- Does not use fluorscent a Regular trash bin

- Glass recycling bin = Hazardous waste

- I do not know

Fig. 7. Opinion assessment of participants regarding disposal of used fluorescent lamp

Appendix 1. Chi-Square analysis of different tables

Appendix 1.1a. Chi-Square test results of the use of different types of lamps in houses of Kuwait

\begin{tabular}{llll}
\hline & Value & Df & P \\
\hline Pearson Chi-Square & 49.698 & 2 & .000 \\
Likelihood Ratio & 49.923 & 2 & .000 \\
Linear-by-Linear Association & 4.686 & 1 & .030 \\
N of Valid Cases & 5237 & & \\
\hline
\end{tabular}

Appendix 1.1b. Posthoc test (after Chi-Square test) results of the use of different types of lamps in houses of Kuwait

\begin{tabular}{|c|c|c|c|c|c|}
\hline & & \multicolumn{3}{|c|}{ Type of lamps are used in household } & \multirow[b]{2}{*}{ Total } \\
\hline & & $\begin{array}{l}\text { Incandes- } \\
\text { cent }\end{array}$ & $\begin{array}{l}\text { Fluores- } \\
\text { cent }\end{array}$ & Both & \\
\hline \multirow{7}{*}{$\begin{array}{l}\text { Do you know the } \\
\text { difference between } \\
\text { the types of lamps } \\
\text { sold in the market? }\end{array}$} & Count & 228 & 1122 & 1343 & 2693 \\
\hline & Percent & $8.5 \%$ & $41.7 \%$ & $49.9 \%$ & $100.0 \%$ \\
\hline & Adjusted Residual & -6.2 & 5.0 & -.9 & \\
\hline & $P^{*}$ & 0.0000000 & 0.0000007 & $\begin{array}{l}0.343585 \\
9\end{array}$ & \\
\hline & Count & 352 & 890 & 1302 & 2544 \\
\hline & Percent & $13.8 \%$ & $35.0 \%$ & $51.2 \%$ & $100.0 \%$ \\
\hline & Adjusted Residual & 6.2 & -5.0 & .9 & \\
\hline \multirow{4}{*}{ Total } & $P^{*}$ & 0.0000000 & 0.0000007 & $\begin{array}{l}0.343585 \\
9\end{array}$ & \\
\hline & Count & 580 & 2012 & 2645 & 5237 \\
\hline & Percent & $11.1 \%$ & $38.4 \%$ & $50.5 \%$ & $100.0 \%$ \\
\hline & rected/adjusted $p$ value & & & & \\
\hline \multicolumn{6}{|c|}{ (2) } \\
\hline & Value & Df & & $\mathbf{P}$ & \\
\hline Pearson Chi-Square & $7490.150^{\mathrm{a}}$ & 8 & & 0.000 & \\
\hline $\begin{array}{l}\text { Likelihood Ratio } \\
\mathrm{N} \text { of Valid Cases }\end{array}$ & $\begin{array}{l}4103.393 \\
7462\end{array}$ & 8 & & 0.000 & \\
\hline
\end{tabular}

products, wearing rubber gloves for cleanup, cleaning by small pieces of cardboard, and finally using sticky tape to remove the fragments and powder. All the items must be disposed of in a sealed and double wrapped plastic bag, which should be dropped in a local hazardous waste drop-off location.

The last question was related to the disposal of the spent fluorescent lamps. This question excluded $11.1 \%$ of the respondents who do not use fluorescent lamps in their households (Fig. 7). The results showed that $79 \%$ of the respondents would discard the spent fluorescent lamps in general waste bins, $6.7 \%$ would discard them and the rest did not know the proper disposal route. This shows that a tiny segment of society $(3.5 \%)$ is aware of the proper disposal of fluorescent lamp waste, which is dropping a local hazardous waste drop-off location (Health Protection Agency, 2009). Finally, on inquiring whether respondents knew of any establishments in Kuwait that accept fluorescent lamps, the vast in glass recycling bins, $3.5 \%$ in hazardous waste bins, 
Appendix 1.2b. Posthoc test (after Chi-Square test) results of the reasons for using fluorescent lamps in houses of Kuwait

\begin{tabular}{|c|c|c|c|c|c|c|c|c|}
\hline & & & & asons of us & g fluorescen & lamps & & \\
\hline & & & $\begin{array}{l}\text { Does not use } \\
\text { fluorescent }\end{array}$ & $\begin{array}{l}\text { It has a } \\
\text { long life }\end{array}$ & $\begin{array}{l}\text { It is readily } \\
\text { available in } \\
\text { the market }\end{array}$ & $\begin{array}{l}\text { It is } \\
\text { well } \\
\text { priced }\end{array}$ & $\begin{array}{l}\text { It } \\
\text { saves } \\
\text { energy }\end{array}$ & Total \\
\hline & & Count & 0 & 1756 & 451 & 340 & 1378 & 3925 \\
\hline & Both & $\begin{array}{l}\text { Adjusted } \\
\text { Residual }\end{array}$ & -26.4 & 6.8 & 3.3 & 6.5 & 2.3 & \\
\hline & & $\mathrm{P}^{*}$ & 0.0000000 & 0.0000000 & 0.0011435 & 0.0000 & 0.01934 & \\
\hline Options to & & Count & 0 & 1310 & 325 & 171 & $\begin{array}{l}1151 \\
1151\end{array}$ & 2957 \\
\hline by the & Fluorescent & $\begin{array}{l}\text { Adjusted } \\
\text { Residual }\end{array}$ & -20.3 & 4.6 & 1.4 & -3.0 & 7.4 & \\
\hline participants & & $\mathrm{P}^{*}$ & 0.0000000 & 0.0000049 & 0.1750483 & 0.0031 & 0.00000 & \\
\hline & & Count & 580 & 0 & 0 & 0 & 0 & 580 \\
\hline & Incandescent & $\begin{array}{l}\text { Adjusted } \\
\text { Residual }\end{array}$ & 86.4 & -20.9 & -8.5 & -6.8 & -18.0 & \\
\hline & & $P^{*}$ & 0.0000000 & 0.0000000 & 0.0000000 & $\begin{array}{l}0.0000 \\
000\end{array}$ & $\begin{array}{l}0.00000 \\
00\end{array}$ & \\
\hline Total & & Count & 580 & 3066 & 776 & 511 & 2529 & 7462 \\
\hline & & ${ }^{*}$ Bonfer & rrected/adju & $p$ value & & & & \\
\hline
\end{tabular}

Appendix 1.3. Chi-Square test results on awareness of the presence of mercury in fluorescent lamps and its impact on human health and the environment

\begin{tabular}{llll}
\hline & Value & Df & P \\
\hline Pearson Chi-Square & $874.073^{\mathrm{a}}$ & 2 & 0.000 \\
Likelihood Ratio & 916.590 & 2 & 0.000 \\
N of Valid Cases & 15711 & & \\
\hline
\end{tabular}

Appendix 1.4. Chi-Square test results on awareness of immediate actions required after a fluorescent lamp is broken

\begin{tabular}{llll}
\hline & Value & Df & P \\
\hline Pearson Chi-Square & $1132.115^{\mathrm{a}}$ & 2 & 0.000 \\
Likelihood Ratio & 1127.557 & 2 & 0.000 \\
N of Valid Cases & 15711 & & \\
\hline
\end{tabular}

majority $(95.6 \%)$ of them were unaware of any place that accepts used fluorescent lamps.

\section{Conclusion}

Mercury is an essential component of fluorescent lamps, which can prove harmful to humans and the environment. The focus of this study was to assess the awareness of the community for this problem and raise public awareness regarding proper usage, disposal, and recycling of fluorescent lamps. The opinion survey indicated that $50.5 \%$ of the respondents used both incandescent and fluorescent lamps, while $38.4 \%$ used only fluorescent lamps due to long lifespan $(65.8 \%)$ or energy-saving properties (53.3\%), yet $81.6 \%$ of them were not aware of the presence of mercury in fluores- cent lamps and its consequences. Only $45 \%$ have an idea about mercury's impact on human health, while $36.6 \%$ suspected it would affect the environment. About $35.8 \%$ of participants were unaware of possible transmission mechanisms of mercury into the human body through inhalation or the epidermis. The lack of awareness in the community of Kuwait regarding fluorescent lamps could be due to the poor acquaintance of suitable actions for proper disposal of pieces if a fluorescent lamp accidentally breaks or when it completes its life. These probable consequences necessitate arranging appropriate awareness and training campaigns of communities by health organizations, environmental organizations, and government entities to avoid possible health and environmental shortfalls in Kuwait. Large furniture and electronics retailers can initiate nationwide CFL take-back programs to increase the number of recycled lamps and reduce the quantity that would eventually be discarded. It is recommended that these programs be at no additional cost to the consumer to increase the participation rate.

\section{ACKNOWLEDGEMENTS}

The authors of this study would like to thank the 38 collectors who helped gather the data and complete this large-scale survey, Kuwait University for providing the statistical software package, Muhammad Islam for proofreading this manuscript, and all the survey participants.

\section{Conflict of interest}

The authors declare that they have no conflict of interest. 


\section{REFERENCES}

1. Abotalib, M., Jaya, J., Al Hamadi, H. A. H., \& Alkandari, D. (2021). The environmental cost and benefits analysis of different electricity options: a case study of Kuwait. Journal of Engineering Research, 9(2), 308-319. https://doi.org/10.36909/jer.v9i2.9853

2. Agency for Toxic Substances and Disease Registry (ATSDR) (2011) Mercury. Available online at https:// www.atsdr.cdc.gov/substances/toxsubstance. asp?toxid $=24$.

3. Ansari, D. \& Holz, F. (2020). Between stranded assets and green transformation: Fossil-fuel-producing developing countries towards 2055. World Development, 130, 104947. https://doi.org/10.1016/j.worlddev.2020.104947

4. Aucott, M., McLinden, M. \& Winka, M. (2003). Release of mercury from broken fluorescent bulbs. Journal of the Air \& Waste Management Association, 53(2), 143-151. https://doi.org/10.1080/10473289.2003.10466132

5. Brautigam, J. (1997). Compact Fluorescent Lamps. Washington State University, Olympia. Available online at: https://research.wsulibs.wsu.edu/xmlui/bitstream/ handle/2376/6870/eb1845e.pdf?sequence=1\&isAllowed=y

6. Counter, S. A. \& Buchanan, L. H. (2004). Mercury exposure in children: a review. Toxicology and Applied Pharmacology, 198(2), 209-230. https://doi.org/10.1016/j.taa p.2003.11.032

7. Dunmire, C., Calwell, C., Jacob, A., Ton, M., Reeder, T., \& Fulbright, V. (2003). Mercury in Fluorescent Lamps: Environmental Consequences and Policy Implications for Natural Resources Defense Council (NRDC). Final Report, Ecos Consulting, 36p, Australia.

8. Gaffuri, P., Stolyarova, E., Llerena, D., Appert, E., Consonni, M., Robin, S., \& Consonni, V. (2021). Potential substitutes for critical materials in white LEDs: Technological challenges and market opportunities. Renewable and Sustainable Energy Reviews, 143, 110869. https:// doi.org/10.1016/j.rser.2021.110869

9. Hansen, J., Johnson, D., Lacis, A., Lebedeff, S., Lee, P., Rind, D., et al. (1981). Climate impact of increasing atmospheric carbon dioxide. Science, 213(4511), 957-966. https://doi.org/10.1126/science.213.4511.957

10. Health Protection Agency (2009). Fact sheet on mercury and compact fluorescent lamps (CFLs - Energy Saving Light Bulbs). Available online at https:// webarchive.nationalarchives.gov.uk/20100303194734/ http://www.hpa.org.uk/webw/HPAweb\&HPAwebStandard/ HPAweb_C/1207293983993? $p=115831343$

11. Hill, M. K. (2020). Understanding environmental pollution. Cambridge University Press.

12. IARC (2018). The IARC Monographs on the Evaluation of the Carcenogenic Risks to Humans. Available online at https://monographs.iarc.fr/agents-classified-by-the-iarc/.

13. IBM (2019). Statistical Package for the Social Sciences (SPSS). Armonk, NY: IBM Corp.
14. Jang, M., Hong, S. M., \& Park, J. K. (2005). Characterization and recovery of mercury from spent fluorescent lamps. Waste management, 25(1), 5-14. https:// doi.org/10.1016/j.wasman.2004.09.008

15. Johnson, N. C., Manchester, S., Sarin, L., Gao, Y., Kulaots, I., \& Hurt, R. H. (2008). Mercury vapor release from broken compact fluorescent lamps and in situ capture by new nanomaterial sorbents. Environmental Science \& Technology, 42(15), 5772-5778. https://doi.org/10.1021/ es8004392

16. Khan, N. \& Abas, N. (2011). Comparative study of energy saving light sources. Renewable and Sustainable Energy Reviews, 15(1), 296-309. https://doi.org/10.1016/ j.rser.2010.07.072

17. Li, C., Shen, J., Zhang, J., Lei, P., Kong, Y., Zhang, J., et al. (2021). The silver linings of mercury: Reconsideration of its impacts on living organisms from a multi-timescale perspective. Environment International, 155, 106670. https://doi.org/10.1016/j.envint.2021.106670

18. Lim, S. R., Kang, D., Ogunseitan, O. A., \& Schoenung, J. M. (2013). Potential environmental impacts from the metals in incandescent, compact fluorescent lamp (CFL), and light-emitting diode (LED) bulbs. Environmental Science \& Technology, 47(2), 1040-1047. https://doi.org/10.1021/ es302886m

19. Murphy, M.P., Staffileno, B.A., \& Foreman, M.D. (2018). Research for Advanced Practice Nurses: From Evidence to Practice, 3rd ed., New York, NY: Springer.

20. State of Kuwait Directorate General of Civil Aviation (SKDGCA) (2017). Climate History. Available online at http://www.met.gov.kw/Climate/climate_hist.php? lang=eng.

21. Nance, P., Patterson, J., Willis, A., Foronda, N., \& Dourson, M. (2012). Human health risks from mercury exposure from broken compact fluorescent lamps (CFLs). Regulatory Toxicology and Pharmacology, 62(3), 542-552. https://doi.org/10.1016/j.yrtph.2011.11.008

22. Ngoffe, S. P. (2019). Harmonic Investigation of Compact Fluorescent Lamps Low Energy Consumption Lamps of Cameroonian Market. Open Access Library Journal, 6 (05), 1. https://doi.org/10.4236/oalib.1105446

23. Pode, R. (2020). Organic light emitting diode devices: An energy efficient solid state lighting for applications. Renewable and Sustainable Energy Reviews, 133, 110043. https://doi.org/10.1016/j.rser.2020.110043

24. SurveyMonkey Inc. (SMI) (2020). Using skip logic in a survey. [Online]. Available online at www.surveymo nkey.com

25. The U.S Energy Information Administration (USEIA) (2016). Country analysis brief: Kuwait. Macron Int. Inc., Copeville.

26. Yang, F. \& Massey, I. Y. (2019). Exposure routes and health effects of heavy metals on children. Biometals, 32 (4), 563-573. https://doi.org/10.1007/s10534-019-00193-5 